\title{
ОБЗОРЫ
}

\author{
Laura Madella
}

\section{CHILDREN'S LITERATURE IN ITALIAN JOURNALS: AN OVERVIEW}

In the Italian landscape, the dissemination of scholarly research on children's literature is influenced by the fact that the disciplinary division of academic knowledge generally considers children's literature as a branch of History of Education, more rarely as one of Philosophy of Education and, when dealing with children aged 3-5, as a part of Early Childhood Education. For this reason, essays on books and writings for young people often appear in journals mainly devoted to the alleged "major" pedagogical subjects, with some notable exceptions. As a whole, children's literature today is a well-developed academic field in Italy, with regular international exchanges on the subject matter. Such academic divisions influence the very field of publications devoted to children's literature: it is represented by academic journals that include children's literature in a broader research scope, and specialized journals, often initiated outside the academic world and addressed to a larger audience of readers, parents, educators, and those who express their interest in the subject matter.

Among the academic journals, the official bulletin of the SIPED Association (Italian Pedagogical Society), Pedagogia Oggi ("Pedagogy today"), which publishes articles both in Italian and English, hosts articles in all areas of educational studies and therefore also prints research on children's literature. This subject also appears often in the online journal Nuova Secondaria Ricerca ("New High School Research"), which is the academic branch of Nuova Secondaria ("New High School"), a professional journal for high school teachers and administrators. Another publication, Bambini ("Children"), which is

Laura Madella

Università di Parma,

Parma

laura.madella@unipr.it 
printed in Parma with ten issues annually by the publishing house Spaggiari, is committed to literature for early childhood educators. As far as literature written for young people aged six and older, Studi sulla formazione ("Studies on Education") should be mentioned. It has been in circulation since 1997 and it is published by the Department of Education of the University of Florence. It regularly publishes articles on works and authors of children's literature placing them into a broader philosophical and historical perspective. The journal is international, peer-reviewed, open-accessed and biannual. This journal is close in spirit and material to Educazione. Giornale di pedagogia critica ("Education. A journal of critical thinking on pedagogy"), founded by the editors-inchief Francesco Mattei and Benedetto Vertecchi. The scholarship that appears in Edicazione addresses the broader historical-theoretical scope. Rivista di Storia dell'Educazione ("History of Education Journal"), the official journal of CIRSE (Italian Center for History of Education) and together with the society's bulletin, was initiated in 1981, simultaneously with the institution itself. The focus of these two publications is mainly on the historical issues of childhood, education, and children's literature as a part of the educational process.

The dual nature of the discipline in the Italian context is clearly reflected in the title of the journal History of Education and Children's Literature (HECL), which is the official publication of the Centre for Documentation and Research on the history of schoolbooks and children's literature. This journal was established in 2004 at the University of Macerata, its editor-in-chief is Roberto Sani. The journal's title makes children's literature scientifically equal to the history of education and, actually, the growing number of contributions devoted to children's literature substantiates the purpose. HECL comes out twice a year, and it is mainly written in English.

As mentioned above, there are some renowned journals entirely devoted to children's literature which are in part related to the academic milieu, but were first promoted by different, though influential, cultural institutions. LG Argomenti (LG) has been the official magazine of the Edmondo De Amicis International Library in Genoa since its foundation in 1965 even though, at that time, its name was Il Minuzzolo (from a work's title by Pinocchio's author Carlo Collodi). In 1976, this publication was renewed and renamed (LG means "Letteratura Giovanile", "Juvenile Literature") under the guidance of Pino Boero, Professor of Children's literature at the University of Genoa. The magazine's critical approach focuses on the latest book publications, however, the historical perspective on the development of children's 
literature is still preserved. LG deals with movies, works of music and visual art as well, as long as the subject matter is children's literature and culture. Such an interdisciplinary and contemporary approach appeals to an audience not necessarily made of scholars, but also to educators and people involved into the cultural life of children, i.e. families, librarians, etc.

Pagine Giovani ("Young pages", established in Rome, 1976) combines the study of the subject from the historical perspective with a more contemporary one but the priority is given to the immediate needs and practical demands of jobs in education. It represents the official voice of the Gruppo di Servizio per la Letteratura Giovanile (Service Association for Juvenile Literature, GSL), devoted to study of children's literature. The group is also actively engaged into promotion of reading among young people. Thus, Pagine Giovani deals with teaching practices and didactics of reading as well. The journal publishes book reviews but also critiques cultural products such as comics, movies, animated films, shows. The journal does not escape discussing such a highly debatable issues as formal and informal education.

Among the most authoritative journals predominantly addressed to librarians, educators and teachers, is the monthly Andersen, once again established in Genoa (1982) but claiming itself independent from any institutions. It offers critical essays on books and cultural trends and embraces a journalistic writing style in order to involve readers and encourage them to look at literary and artistic production for children from a critical point of view. One of the obvious strengths of this publication is its devotion to graphic design and artwork. The bibliographical reviews include Italian and non-Italian authors and the reviews of cultural events, such as various book festivals. The journal devotes the summer issues (June and July) to a monographic survey, usually dealing with either an author (2016: Roal Dahl), a literary work (2015: Alice in Wonderland), or a concept (2018: Mountains; 2019: Educational deprivation). Andersen created and still promotes the "Andersen Award" for books, authors, illustrators and editors of children's literature (age 0-18).

Another significant city in Italian geography of children's literature is Bologna, where the cultural association Hamelin is located that also publishes two journals: Hamelin that comes out six times a year and the annual Oblo ("Porthole"). The Association is located in via Zamboni, the headquarter and historical heart of the University, and has been established since 1996 by a group of scholars gathered around Antonio Faeti, Professor of Children's literature with strong interest in 
readers' figurative experience. The primary purpose of the group is to enhance reading among young people and educate adults how to assist in promoting reading among the young audience. The Association's activities range from training courses for adults (for instance, how to read graphic novels, popular science books, or video games' graphics) to educational projects that feature schools and libraries (the most successful: Xanadu, aimed at ages from 12 to 17.) The journal's articles are on a critical perspective focused on the relationship between works and the audience.

Hamelin. Storie figure pedagogia ("Histories, pictures, pedagogy") is composed of five-section with each section including essays and reading recommendations. Hamelin also devotes its pages to the most current events, such as, for example, an obituary of the Belgian illustrator, Mario Ramos, who passed away in 2012. Oblò's monographic entries are devoted to renowned authors of children's literature and picture books, such as Gilles Bachelet and Sergio Ruzzier. Promoting reading and educating readers is the ultimate goal of Il Pepeverde ("The Green Pepper", est. Rome 1999), whose director, Ermanno Detti, has been closely related to the pedagogical circle of Tullio de Mauro and Franco Frabboni. Il Pepeverde's editorial board is particularly committed to school issues and so are many of its contributions. The critical approaches in the entries in this journal is aimed at the daily experience and reflection of teachers, librarians and educators. Finally, I would like to mention $L i B e R$, an actual quarterly bulletin of bibliographical news published in Italy. In those entries one can find not only bibliographical news, but also critical insights. Its editorial board includes scholars from the leading Italian academies. LiBeR is issued by the Library of Campi Bisenzio (Florence) and is distributed to libraries in Italy.

Of course, this brief overview does not fully capture the world of scholarship in children's literature in Italy. Nevertheless, it demonstrates how active and diverse the present status of research in children's literature in Italy is. It continues to develop and it addresses new issues, presents interdisciplinary methodology, and opens new venues of investigation for both scholars and readers. 


\section{Laura Madella}

Università di Parma

CHILDREN'S LITERATURE ON ITALIAN JOURNALS: AN OVERVIEW

The paper introduces the reader to the most influential Italian journals dedicated to children's literature, domestic and foreign. It offers an overview of these journals' themes, features, and content. Italian scholarship in children's literature today represents an engaging field of academic research, often connected with the major directions in educational studies, such as the history and philosophy of education. Thus, scholarly outcome of the latest research in children's literature is usually distributed throughout major professional journals, generally led by university-based research groups. These journals offer critical essays with a comparative perspective, not only from a geographic (non-Italian literature, non-Italian authors) but also from a crossdisciplinary point of view (history and philosophy, as well as social science, visual arts, methodology, etc.). Such academic centers at universities in Rome, Florence, Macerata, Bologna, and Genoa support the rich tradition of educational and literary studies. They also host authoritative academic journals, as well as influential periodicals edited by non-academic cultural institutions, libraries and the like, whose main purpose is to enhance reading practices among young people. For this reason, articles in such periodicals privilege contemporary literature (in all its artistic venues), investigate the relationship between literary works and their audiences, and often focus on educational settings and their adult actors (schools and teachers, libraries and librarians).

Keywords: Children's literature, juvenile literature, history of education, literary criticism, reading practices, classroom instruction 